\title{
Pakistan, Growth, Dependency, and Crisis
}

\section{Matthew McCartney*}

\begin{abstract}
Compared to the historical and even contemporary experience of India, Pakistan has long been regarded as a "dependent" economy. Gross domestic product growth in Pakistan is typically argued to be contingent on external factors: trade, financial flows, and the interdependence of asset markets. Beyond the rhetoric, there is only ambiguous and contradictory empirical evidence to support this view. This paper offers a new methodology, that of case studies of growth and stagnation, to test the hypothesis of dependency. The results show that growth in Pakistan is influenced by external factors, but that growth is driven primarily by the dynamics of the domestic economy.
\end{abstract}

Keywords: Economic Growth, Dependency, Crisis, Pakistan.

\section{JEL Classification: F43, O16.}

\section{Introduction}

There is an ongoing debate about the impact of trade, foreign direct investment (FDI), and financial liberalization on economic growth. Its proponents favor a positive link, having been more vocal in recent decades than during the years of import substitution and self-sufficiency in the 1950s and 1960s. The Asian crisis of 1997/98 and current global financial crisis have focused new and more critical attention on the question of global trade and particularly financial links. This article looks at a particular case studythat of Pakistan since independence. There is a common presumption in much of the economic literature that Pakistan is a "dependent" economyits growth and development conditioned on the global economy. Beyond the rhetoric, the empirical evidence offers at best only hesitant and ambiguous support for this hypothesis. This article derives a new (for the case of Pakistan) methodology to examine the link between the global economy and episodes of growth and stagnation in Pakistan. Section 2 looks at the general and Pakistan theoretical and empirical debate, Section 3 discusses the rationale of using this new methodology to examine growth in Pakistan,

* Lecturer in Economics (South Asia), School of Oriental and African Studies (SOAS), University of London. 
Section 4 uses a rigorous statistical methodology to isolate episodes of growth and stagnation, Section 5 tests the "dependency" hypothesis and Section 6 concludes the study. ${ }^{1}$

\section{Dependency and Pakistan: The Debate}

The academic literature examining the link between the global economy and domestic growth is voluminous in both theory and evidence. There is a large literature testing the link between trade liberalization and economic growth (Dollar, 1992; Krueger, 1998; Sachs \& Warner, 1995), FDI, and economic growth (Aitken \& Harrison, 1999; Balasubramanyam, Salisu, \& Sapsford, 1996; Gorg and Greenaway, 2004), foreign aid and economic growth (Burnside \& Dollar, 2000; Guillamont \& Chauvet, 2001) and, after the 1997/98 Asian crisis, a growing appreciation of issues such as contagion and herding that work principally through global financial markets (Krugman, 1999; Stiglitz, 2002; Wade 1998).2 Collectively, these various linkages from the global economy inspire confidence about the positive benefits of globalization in some (Bhagwati, 2004; Wolf, 2004), and views ranging from heavily qualified optimism (Rodrik, 2000) to the hostile, especially among those writing from the perspective of the dependency school (Cardoso, 1972; Frank 1967). During the early years of the recent global financial crisis, a third view gained some prominence-that of "decoupling," which argued that growth in several large developing countries was driven mainly by internal factors and would likely be sustained throughout the crisis (Akin $\&$ Kose, 2007). This optimistic apathy was soon after being questioned for the case of India, among others (Nachane, 2009).

The currently fashionable thesis of "decoupling" makes some historical sense for the case of India. There is no clear evidence to suggest the external economy ever made a significant contribution to driving episodes of growth or stagnation in India. The shift to the (currently) relatively rapid gross domestic product (GDP) growth rates occurred in the late 1970s/early 1980s (Nayyar, 2006). This break occurred in the context of recession in the developed world and the most unfavorable external terms of trade for India since the 1960s (Joshi \& Little, 1994,

\footnotetext{
${ }^{1}$ Many thanks to Grace Kite (SOAS) who did the econometric work in Section 4, which can be read in more detail in Kite and McCartney (2011).

${ }^{2}$ There are other possible links: an external threat may push up military spending, domestic consumers may seek to emulate consumption patterns of more developed countries and so reduce domestic savings, political instability in neighboring countries may spill over-such links are not examined in this article, which focuses on testing more widely debated and narrow economic linkages.
} 
Chapter 6; Rodrik \& Subramanian, 2004). More broadly, in terms of foreign investment, foreign control of key economic sectors such as banks and oil, and domestic self-reliance in modern industrial inputs such as capital goods, India was long insulated from the world economy-the "Indian state has played a decisive role in constructing the most selfreliant and insulated capitalist economy in the third world... There is no major capitalist country in the third world which has a more powerful state than India's or an indigenous bourgeoisie with more autonomy from foreign capital" (Vanaik, 1990, pp. 8, 11). FDI into India after 2003 and GDP growth did increase rapidly, but so too did domestic savings; there is evidence that FDI was more obviously driven by domestic growth than the opposite (Chakraborty \& Nunnenkamp, 2008).

Pakistan has long been regarded as different. A very common unifying hypothesis to explain Pakistan's growth and development has been its dependence on foreign capital inflows. Since 1951, domestic investment has systematically exceeded domestic savings; investment has been substantially funded by foreign capital inflows. For example, in 1974/75, domestic investment was 15.6 percent of GDP and gross domestic savings 4 percent, leaving Pakistan heavily dependent on foreign resource inflows (V. Ahmed \& Amjad, 1984, p. 97). The ebb and flow of capital inflows according to many has been a determining influence on growth rates, as well as exposing Pakistan to policy influence from donors: "US priorities determined Pakistan's domestic and foreign policies from 1951 onward" (Ali, 2008, p. 251). The most dramatic and frequently discussed example in the literature is the "Decade of Development" (1958-1968) under Ayub Khan. In response to Ayub's pro-US foreign policy stance during the Cold War, many argue that a surge of capital inflows generated an investment-led boom until 1965, then declining capital inflows (related to the war with India in 1965) led to economic slowdown (Amjad, 1983; Griffin, 1965).

The intermittent global financial crises since the 1990s have helped scholars provide a framework to clarify the channels of contagion by which the global economy, for good or ill, may impact on the domestic economy. Van Rickenghem and Weder (2001) identify four major channels of contagion: (i) trade channel (merchandise and invisibles); (ii) foreign capital flows; (iii) contamination of financial assets; and (iv) interdependence of asset markets, especially equity, bonds, and housing. For the case of Pakistan, as many other developing economies, we would expect liberalization in trade, FDI, and finance to have increased the potency of these channels over the last 20 years. 
Despite the very strong conclusions regarding Pakistan as being "dependent," there is very little clear evidence to link the global economy to variations in Pakistan's GDP growth. Following the four-point framework described above:

The trade ratio (exports plus imports divided by GDP) is found to have a positive impact on GDP growth (Din, Ghani, \& Siddique, 2003; Iqbal, 1993; Iqbal \& Zahid, 1998; M. A. Khan \& Qayyum, 2007). Exports alone are found to have a positive (Ahmad, Alam, \& Butt, 2003) or no relation with GDP growth (Q. M. Ahmed, Butt, \& Alam, 2000; Akbar \& Naqvi, 2000). Exports are also found to have a positive relationship with household saving (Iqbal, 1993). The external terms of trade are found to have a positive impact on public savings (Iqbal, 1993) and an insignificant effect on domestic savings (Nasir \& Khalid, 2004).

External debt is found to have no relation to GDP growth (Q. M. Ahmed et al., 2000); foreign savings an insignificant impact on domestic investment (Aslam, 1987; Franco-Rodriguez, Morrissey, \& McGillivray, 1998; Nasir \& Khalid, 2004); and FDI a positive (Atique, Khan, \& Azhar, 2004) and a negative (Shabbir \& Mahmood, 1992) relation with GDP growth. World Bank/International Monetary Fund (IMF) adjustment lending is found to have no relation with GDP growth, savings, and foreign borrowing; and a positive impact on investment and government spending (Iqbal, 1994). Foreign aid is found to have a small and positive impact (N. Z. Khan \& Rahim, 1993) and a negative impact (S. R. Khan, 1997) on GDP growth, and also an insignificant impact on domestic savings (A. H. Khan, Hasan, \& Malik, 1992). There is a general and widespread (if not total) agreement that domestic savings have been negatively impacted by foreign capital inflows and are more obviously dependent on domestic policy factors (such as real interest rates, the dependency rate, and expected inflation) (Aslam, 1987; Iqbal, 1993, 1997; S. R. Khan, 1997; Khilji \& Zampelli, 1991; Mahmood \& Qasim, 1992; Nasir \& Khalid, 2004; Qureshi, Din, Ghani, \& Abbas, 1997; Shabbir \& Mahmood, 1992).

There is evidence that domestic financial markets in Pakistan have become more integrated with both the world economy and with Pakistan's real domestic economy over the era of liberalization. Uppal (1993) finds that volatility on foreign stock markets, particularly in Asia and going right back to the 1960s, have affected the stock market in Pakistan. There is also evidence that financial liberalization from the 1990s onward, strengthened interlinkages between stock prices and macroeconomic variables in Pakistan (F. Husain \& Mahmood, 2001). In particular, there exists a causal 
relationship from the currency market to the stock market and from the stock market to the money market (Khalid \& Rajaguru, 2006). There is, though, stronger evidence that domestic investment strategies have driven the volatility of Pakistan's stock market (Farid \& Ashraf, 1995; Hameed \& Ashraf, 2006; F. Husain \& Mahmood, 2001).

\section{A New Method for Exploring Economic Growth}

This section reviews existing work on economic growth in Pakistan. There is a steadily accumulating literature (some of it reviewed in the previous section) derived from Barro (1991) using time series data for Pakistan or else running large cross-country regressions and focusing on the implications of the findings for Pakistan. The usual suspects make their appearance as independent variables: initial income, education, investment, government spending, etc. This literature is gradually absorbing theoretical progress into its methodology, and procedures such as testing for stationarity and causation/endogeneity are now the norm (Ahmad et al., 2003; Atique et al., 2004; Din et al., 2003; Ghani \& Din, 2006; Iqbal, 1994; Iqbal \& Zahid, 1998; M. A. Khan \& Qayyum, 2007, etc).

This literature reflects the wider problems of crosscountry/state/time series growth regression. Many theoretically important policies such as trade liberalization or government intervention are notoriously difficult to measure for the sake of regression analysis. For Pakistan, crude proxies for "government intervention" such as "government consumption or defense spending" or "the budget deficit" have no clear relation with GDP growth (Ghani \& Din, 2006; Iqbal \& Zahid, 1998; Tahir, 1995). This is not surprising. Knowles and Garces-Ozanne (2003) found that measures of government spending are a very poor statistical proxy for the government's actual influence on the economy. A tax cut and a subsidy, for example, may have identical economic impacts but would have very different implications for the measured size of state intervention. In a wider literature, government spending has no robust relation to GDP growth (Levine \& Renelt, 1992, p. 951).

Case studies offer important benefits for the study of economic growth. They enable greater attention to the causal mechanism (rather than the statistical significance) linking, for example, policy and growth (Gerring, 2007; Wacziarg, 2002). All intervening steps between cause and effect can be taken into account, and each step can be preceded by a hypothesis (Gerring, 2007, p. 181). A focus on the causal mechanism would allow case studies to examine the relation between different theories of 
growth, the assumption of universalism in the growth process, ${ }^{3}$ and contingent causes of growth, 4 all of which have been identified as particular problems for regression analysis (Kenny \& Williams, 2001; McCartney, 2009; Temple, 1999). This advantage is exploited in this article.

A common criticism of the case study methodology is that it has no formal method of case study selection (George \& Bennett, 2005). The typical pattern of economic growth in developing countries suggests a rigorous methodology with which to choose case studies. In least developed countries (LDCs), there is little correlation between growth rates across different time periods (Easterly, Kremer, Pritchett, \& Summers, 1993; Easterly \& Levine, 2001; Maddison, 1995), and growth is best characterized as occurring in episodes of growth and stagnation (Berthelemy \& Soderling, 2001; Hausman, Pritchett, \& Rodrik, 2004; Mkandawire, 2001; Rodrik, 2003; Temple, 1999); this has also been found to be true at state level in India (Dholakia, 1994). Such shifts or episodes in growth also represent easily identifiable case studies. It is these considerations that motivate the empirical analysis given in Section 4 below. The analysis there identifies episodes of growth and stagnation in Pakistan that offer a rigorous method with which to choose case studies.

A problem with many growth regressions is that they crowd in the deeper (institutions, geography, culture, history, etc.) and proximate (trade policy, taxation, investment, etc.) causes of growth into the same regression analysis. Theory, however, suggests the latter affect growth through the former. Strong institutions (property rights) increase the incentive for private agents to invest. Poor geography (a country being landlocked) reduces the impact of trade liberalization on growth. Looking at distinct episodes of growth allows us to avoid this methodological problem. The deeper determinants of growth are likely fixed in the short term and change only slowly over the longer term. It is unlikely that culture or geography will change quickly and significantly enough to be responsible for structural breaks in economic growth. The methodology

\footnotetext{
${ }^{3}$ Cross-country growth regressions assume that economic growth operates according to universal laws across all economies and through time and space. Each individual country/state then provides evidence used to elucidate this one underlying universal economic relation (regression parameter). An increase in education, for example, is hypothesized to have the same effect on growth in all countries/states.

${ }^{4}$ In econometric analysis, variables typically enter the right-hand side of regressions separately without diagnostic tests allowing for any but very limited interaction among them. Theory does suggest that complementarity is important. For example, investment may be only causally related to growth in the presence of strong property rights, reforms causally related to growth only if considered credible or if correctly sequenced.
} 
used in this article allows us to focus more precisely on policy, trade flows, etc. as determinants of growth in Pakistan.

\section{Identifying Episodes of Growth and Stagnation}

This section presents the results of a statistical analysis of GDP growth in Pakistan since independence. The analysis seeks to identify episodes of growth and stagnation in GDP. The data reveals that there have been five broad episodes of growth and stagnation in Pakistan since independence. These are three episodes of growth-1951/52 to 1958/59, $1960 / 61$ to $1969 / 70$, and $2003 / 04$ to $2008 / 09$-and two episodes of stagnation-1970/71 to $1991 / 92$ and $1992 / 93$ to $2002 / 03$. The evidence for the breaks in $1970 / 71$ and $2003 / 04$ is slightly weaker, but such evidence has been often accepted in the related literature (e.g., Stiroh, 2001, pp. 13-14). There is a broad literature trying to identify episodes of growth and stagnation in India (Balakrishnan \& Parameswaran, 2007; Bhargava \& Joshi, 1990; Hateker \& Dongre, 2005; Kaur, 2007; Nagaraj, 1990; Sinha \& Tejani, 2004; Virmani, 2005; Wallack, 2003), but this work is pioneering for the context of Pakistan.

The classical method for assessing the significance of structural change in the context of an econometric model is the Chow (1960) test. Application of the Chow test would involve splitting the data into two subsamples and then regressing the real GDP growth rates on a constant and any relevant controls. A dummy variable that takes the value 1 for one of the subsamples and 0 for the other would be included and its significance tested using an F-test. A coefficient significantly different from 0 would demonstrate the existence of a breakpoint in that year. In this article, the analysis proceeds by applying the Chow procedure iteratively to all possible splits of the Pakistan data into two subsamples. It is a procedure suggested by Quandt (1960) for application to situations where there is no candidate breakpoint hypothesized in advance. Quandt's method involves estimating T-1 equations, where $\mathrm{T}$ is the sample size, and assessing the significance of T-1 dummy variables by calculating T-1 F-statistics. The largest of these (supF) can then be the subject of a test whose null hypothesis is no breakpoint versus the alternative that there is a break in the year where the maximum F-statistic was found. Andrews (1993) took this work forward by deriving the correct critical values for the procedure. Vogelsang (1997) and Hansen (1997) extended the theme further by modifying the critical p-values for models with serial correlation. 
Applying Quandt's (1960) methodology to the Pakistan GDP data begins by assessing which control variables should be included in the test equations, and which of Andrews' (1993) or Volgelsang's (1997) critical values are appropriate. Various lagged values of GDP growth are tested as controls and found to be insignificant, so a baseline equation using just a constant term is used in practice. Breusch-Godfrey's methodology is used to test for serial correlation and the resulting p-values are all well over 10 percent, so we can conclude that there is no serial correlation problem and Andrews' critical values are appropriate for the QuandtAndrews (Q-A) test.

The next step is to carry out the Q-A test using the chosen test equation over the whole of the sample period, and testing for the significance of a breakpoint in the year with the maximum F-test. It is a significance test that takes into account a "small subsample" problem where the test statistic is degenerative when small subsamples contain too few observations. To compensate for this, it is generally suggested that the ends of the sample period not be included in the testing procedure. A standard level for this "trimming," followed here, is 15 percent, with the first and last 7.5 percent of the observations in the test equation ruled out as potential breakpoint years. The procedure generally followed for overcoming the "two-way split" problem is to identify the first breakpoint and then repeat the Q-A test using a test equation that only includes the period after that year. This process can be repeated until there are no more significant supF statistics (Wallack, 2003, p. 4312).

Table 1 below presents the results of following this procedure on Pakistan's GDP data. The episodes of growth and stagnation identified by the Q-A test have been presented as simple mean growth rates for each of the possible splits of the sample. The first column splits the sample only at the significant breakpoint in 1960/61, while the second column also accepts a breakpoint in 1992/93. The final case where there are five different episodes of growth and stagnation in the post-independence period is in the last column. 
Table 1: Average Growth Rates in Periods between Breakpoints

\begin{tabular}{lccc}
\hline Period & 1 Breakpoint & 2 Breakpoints & 5 Breakpoints \\
\hline $1951 / 52$ to $1958 / 59$ & $3.1 \%$ & $3.1 \%$ & $3.1 \%$ \\
$1960 / 61$ to $1969 / 70$ & $5.4 \%$ & $5.9 \%$ & $6.8 \%$ \\
$1970 / 71$ to $1991 / 92$ & & & $5.6 \%$ \\
$1992 / 93$ to $2002 / 03$ & & $4.5 \%$ & $3.7 \%$ \\
2003/04 to $2008 / 09$ & & & $5.9 \%$ \\
\hline
\end{tabular}

Source: Kemal, A. R., Din, M. U., \& Qadir, U. (2006). Economic growth in Pakistan. In K. S. Parikh (Ed.), Explaining growth in South Asia. New Delhi, India: Oxford University Press. Author's calculations.

It seems clear from these results that the 1960/61 breakpoint can be accepted. However, all the other three breakpoints need to be treated with some caution. 1992/93 emerges as the most likely of the other three principally because it has the highest maximum F-stat and the lowest pvalue. Evidence for potential breakpoints in 1970/71 and/or 2003/04 is weaker, but cannot be discounted. $1970 / 71$ is likely to be a breakpoint that the methodologies used here are ill suited to identify. Its position between two more significant breakpoints clearly identifies it as a possible victim of a "two-way split" problem, which as we have seen can be solved only by performing the Q-A test on a much smaller sample where the test has much less power to find a significant breakpoint. As for the truth of a breakpoint in 2003/04, more time will be the best solution to the "small-sample problem" here.

\section{Episodes of Growth and Stagnation and the Dependency Hypothesis}

This section looks at the episodes of growth and stagnation that were identified in Section 4, and examines to what extent they can be explained by factors external to Pakistan-the dependency hypothesis. It is worth noting at this point that the terms episodes of "growth" and "stagnation" are used relatively, not in an absolute sense. Thus, the episode of stagnation 1970/71 to 1991/92 experienced reasonable rates of economic growth (5.6 percent) but is referred to as an episode of stagnation because it witnessed a statistically significant decline in the growth rate over the immediately preceding period, $1960 / 61$ to $1969 / 70$ (6.8 percent).

\subsection{An Episode of Growth, 1951/52 to $1958 / 59$}

There is no evidence that favorable impacts from the world economy initiated or sustained the episode of growth after 1951/52. The 
episode of growth did begin with an improvement in Pakistan's external terms of trade (Burki, 1999, p. 112; A. I. A. Islam, 1961, pp. 59-60; Papanek, 1967, p. 15). The effect was neither long-lived nor large enough in its aggregate impact to explain the decade-long episode of growth. As the Korean War came to an end, there was a collapse in Pakistan's terms of trade, from 125 in 1950/51 to 84 in 1952/53, and a low of 52 in 1959/60 (A. I. A. Islam, 1961, pp. 59-60; Lewis, 1970, p. 126; Papanek, 1967, p. 15). Over the early 1950s, foreign trade shrank in terms of its aggregate importance to Pakistan's economy. Between 1950 and 1955, exports declined from 10.4 to 3.4 percent of GDP and imports from 9.0 to 5.4 percent (I. Husain, 1999, p. 324; Lewis, 1969, p. 47).

\subsection{An Episode of Growth, 1960/61 to $1969 / 70$}

The most common evidence for the dependency hypothesis is the era of Ayub Khan's dictatorship (1958-1968); there is, at best, only weak evidence for this proposition. In response to Ayub's pro-US foreign policy stance during the Cold War, some argue that a surge of capital inflows generated an investment-led boom until 1965, then declining capital inflows (related to the war with India in 1965) led to economic slowdown and debilitating domestic conflict over the more limited foreign largesse (Amjad, 1983). Between 1960 and 1965, a government sanction for an investment project came with the ability to obtain the necessary foreign exchange from the Pakistan Industrial Credit and Investment Corporation (PICIC) or Industrial Development Bank of Pakistan (IDBP) at the official exchange rate. Such loans were significantly below the market rate and had low interest rates. PICIC and IDBP financed about 40 percent of total gross investment in the early 1960s, and provided about 70 percent of the foreign exchange component of investment for such loans (Amjad, 1982). Foreign economic assistance increased from 2.8 percent (40 percent of domestic investment) in 1959/60 to 6.6 percent of GDP (38 percent of domestic investment) in 1964/65, then declined to 3.8 percent of GDP (23 percent of investment) in 1969/70 (N. Islam, 1972, p. 503). There seems at first glance to be a strong association between the behavior of investment and the inflow of real resources between 1960 and 1965. Some agree: the "entire social and economic system, and the planning exercise which is its manifestation, is supported and sustained by foreign assistance" (Griffin, 1965, p. 621) and the "entire edifice had been built upon these large doses of foreign capital, their reduction threatened the entire system" (Amjad, 1983, p. 264). The timing is more difficult to account for than these explanations allow. M. H. Khan (2000) notes that total investment continued to rise until 1968, long after foreign 
aid had slowed. Rather, he argues that growth slowed down in response to increased pressures on the Ayub government to allocate resources according to political rather than economic criteria in response to the growing opposition to his regime after the mid-1960s. This took the form of efforts to build up a Bengali bourgeoisie in East Pakistan. By the midto late 1960s, large resource transfers meant that East Pakistani industrialists often needed barely 10 percent of the required capital to start an enterprise. Such efforts were reasonably successful in raising the profitability of investment in East relative to West Pakistan, but in the short run reduced the growth impact of investment (Amjad, 1982, p. 68).

Measures of the external terms of trade offer some support for the view that a positive shock from the world economy could have been behind the acceleration of growth in the early 1960s. There was an improvement in Pakistan's external terms of trade (Lewis, 1970, p. 126; Papanek, 1967, p. 15) although there is reason to believe that the role of foreign trade was simply too small for this improvement to have much aggregate influence. The ratio of exports to GDP stagnated at 4.5 percent between 1960 and 1965, and then declined to 3.7 percent by 1970 (I. Husain, 1999, p. 324).

There are only rough estimates for FDI in Pakistan over the 1960s. The State Bank of Pakistan estimated that FDI averaged Rs80 million p.a. over the 1960s (Chaudhry, 1970). There is reason to believe that positive spillovers from even this low level of FDI would have been negligible. Typically, foreign firms had such restrictive clauses on the use of the technology that positive spillovers to the rest of the domestic economy would likely have been negligible (Radhu, 1973). Predictably, Shabbir and Mahmood (1992) find that, after 1959/60, there was no significant correlation between FDI and GDP.

\subsection{An Episode of Stagnation, 1970/71 to 1991/92}

Some studies have linked the slowdown of GDP growth after $1970 / 71$ to external factors, but there is no clear evidence of this proposition. Foreign debt increased from 32 percent of GDP in 1969/70 to 37 percent in 1979/80. This modest increase, though, marked a significant increase in the burden of its financing (V. Ahmed \& Amjad, 1984). After the mid-1970s, the average interest rate on foreign borrowing increased, and the average maturity period and average grant element on both declined (S. R. Khan, 1997, pp. 948-949). Debt service payments increased from 25.4 percent of gross disbursements in 1974/75 to 52.1 percent in 
1978/79 (Nawab, Naqvi, \& Sarmad, 1984, p. 101). The real value of foreign loans was reduced further because of the typically 10-15 percent (Griffin, 1965, p. 615) and up to 170 percent (V. Ahmed \& Amjad, 1984) higher price paid on procurements using tied aid. More than 90 percent of total foreign assistance contracted up to December 1980 was tied to specific projects or commodities, and confined to purchases from donors (V. Ahmed \& Amjad, 1984). Increases in global commodity prices (particularly wheat and kerosene) increased the unit value index for Pakistani imports from 155.9 in $1971 / 72(1969 / 70=100)$ to 802.8 in $1979 / 80$. This was offset to some extent by the increased prices of Pakistani exports, from 129.1 to 673.4 . As a result, the terms of trade declined from 100.0 in $1969 / 70$ to 82.8 in $1971 / 72$, rose to 106.4 in $1973 / 74$, fell to 66.7 in $1974 / 75$, and slowly increased to 83.9 in $1979 / 80$ (Nawab et al., 1984, p. 107). Sarmad (1992) has built a computable general equilibrium model of Pakistan's economy that allows us to quantify more exactly the impact of the world economy. He finds that the negative impact of external shocks in the mid-/early 1970s on the current account was not as significant in Pakistan as in other LDCs. In Pakistan, the process of adjustment was underwritten by the dramatic increase in remittance inflows that increased from 0.5 percent of GDP in 1970/71 to 7.5 percent in 1979/80, or from 10.0 percent of the trade gap in 1970/71 to 79.0 percent in 1977/78 (Nawab et al., 1984, p. 97). Remittance income was supplemented by a huge surge in aid from the US related to the Afghan war after 1979. Recession in high-income economies (and hence reduction in world trade growth) was offset by a rising share of the booming Middle East market. Between 1974 and 1982, the share of Organisation of Islamic Countries (mostly oil exporters) increased from 14.0 percent of Pakistani exports to 24.4 percent.

FDI remained negligible throughout the 1970s. It increased from a total of USD41 million between 1970 and 1974 (0.53 percent of gross capital formation) to USD138 million between 1975 and 1979 (0.98 percent), USD322 million between 1980 and 1984 (1.22 percent), and USD764 million between 1985 and 1989 (2.31 percent). (Atique et al., 2004, p. 709). FDI was not a significant component of capital inflow. The share of FDI in total foreign capital inflows increased from 6.77 percent in $1970 / 71$, to 6.96 percent in $1980 / 81$, and 8.62 percent in 1990/91 (Shah \& Q. M. Ahmed, 2003, p. 698). There is very little work on the economic impact of FDI in Pakistan over this period. N. Z. Khan and Rahim (1993) find domestic savings to be positively correlated with FDI, and negatively so with foreign loans. The results hint at a more favorable impact of FDI than other forms of capital inflow, but the results do not for example 
consider the question of causality in the relationship. Shabbir and Mahmood (1992) find that, between 1959/60 and 1987/88, there is no significant correlation between FDI and GDP. Ahmad et al. (2003) meanwhile find a positive relation after 1972.

\subsection{An Episode of Stagnation, 1992/93 to 2003/03}

There is no clear evidence that this episode of stagnation was precipitated by external conditions. The decline in foreign remittance inflows between 1987 and 1990 was the single most important factor leading to deterioration in Pakistan's current account deficit despite significant growth of exports. The Iraqi invasion of Kuwait in 1990 in particular led to a sharp fall of remittance income (and falling exports to Gulf states). Domestic macroeconomic adjustment was successful in that it focused not on expenditure reduction (deflation) but on expenditure switching; hence, changes in domestic absorption variables were small. Devaluation and improved incentives led to adjustment through export growth rather than import decline (Sarmad, 1992, p. 866).

Workers' remittances were replaced by other sources of funds, access to which proved relatively easy in the early 1990s. To attract funds held abroad by Pakistani nationals, nonresident Pakistanis were allowed to open foreign currency accounts with Pakistani banks, which were freely transferable abroad. These accounts were exempted from income and wealth tax and no questions were asked about the source of foreign exchange. Those holding foreign currency accounts could also obtain rupee loans against such accounts (M. A. Khan et al., 2005). Between June 1991 and June 1996, USD4 billion was deposited in domestic foreign exchange accounts (Wizarat, 2002, p. 27).

\subsection{An Episode of Growth, 2002/03 to 2008/09}

There is reasonable evidence to show that this episode of growth was strongly influenced by external factors; internal factors were also important and have often been overlooked by commentators. By the end of the 1990s, servicing the stock of debt had crowded out other forms of public expenditure; it consumed more than 50 percent of budgetary revenues. Annual external debt service payments of USD6 billion-7 billion were required every year (for a total external debt of almost USD38 billion by mid-2001), which was equivalent to two thirds of export earnings. After 11 September 2001, Pakistan gave assurances that it would help the US in Afghanistan. This led to the rapid resumption of financial aid ties with the 
US, World Bank, and IMF-relations that had been suspended after Pakistan conducted nuclear tests in 1998. On 23 September, Bush waved key sanctions and the US voted in favor of the IMF negotiating a Poverty Reduction and Growth Strategy with Pakistan that had been opposed a few days before (Zaidi, 2005). In December 2001, relief was granted to the entire stock of USD12.5 billion owed to the Paris Club (18 key creditor countries). Pakistan benefited from lower interest rates and extended repayment periods. The net present value of the debt stock was consequently reduced by 50 percent and saved USD1.2 billion-1.5 billion in annual servicing costs after 2001. There is one strand of thought that sees growth after 2002/03 as being dependent on this resumption of capital inflows and part of a longer-term argument that sees growth in Pakistan as being ultimately dependent on favorable relations with the US (Ali, 2008).

There is more to the story than the vagaries of US goodwill. September 2001 did lead to a dramatic shift in Pakistan's relations with the outside world that facilitated significant capital inflow, but the strategy to reduce the burden of debt predated 2001 and can be related to domestic reforms initiated by the technocratic managers of the Musharraf government. Between 1999/2000 and 2001/02, the government repaid USD4.5 billion of commercial and short-term debt and made considerable efforts to build up foreign exchange reserves. The external position had been improving since 1999; September 2001 accelerated an existing trend. Between 1999/2000 and 2001/02, the trade gap declined from -USD1.6 billion to -USD1.2 billion, and the current account shifted from a deficit of -USD1.9 billion to a surplus of USD2.7 billion (I. Husain, 2003; Zaidi, 2005). There was a sudden surge in remittances from the US, from USD80 million in 1999/2000 to USD1.2 billion-1.7 billion p.a. after 2001/02. Some have argued this to have been a one-off shift in portfolios in response to tighter banking regulations in the US after September 2001. The remittances from the US continued unabated throughout this episode. Others have argued that much of this represented remittances from more established professionals in the US who were making economic investments in Pakistan (Burki, 2007, p. 260). Higher oil prices toward the end of this episode led to higher remittances from the more traditional Gulf countries, in particular Saudi Arabia and the United Arab Emirates. This again was not related to September 2001.

\section{Conclusion}

This article has used a rigorous statistical methodology to test the hypothesis of "dependent" Pakistan. Economic dependency can be 
manifested through flows of goods and services, finance, or contagion effects through asset markets. Despite some bold claims in the existing academic literature, the empirical evidence for the dependency hypothesis is weak. The statistics of this article have allowed us to isolate episodes of growth and stagnation in Pakistan since 1951, and examine how they were related to changing impacts from the world economy. Our results here echo the poor existing evidence from cross-country growth regressions. Growth in Pakistan is certainly influenced by the world economy, but is primarily dependent on domestic factors, policy, weather, and the nature of state-economy relations. A good example is the recent global financial crisis. GDP growth slowed sharply to 1.2 percent in 2008/09. The slowdown, however, predated the onset of global crisis, growth falling from 6.8 percent in 2006/07 to 3.7 percent in $2007 / 08$, and recovery resumed while the crisis was still raging with GDP growth rising to 4.1 percent in 2009/10. Between 2006/07 and 2007/08, the sharpest falls in growth rates were in those sectors that were least exposed to the global economy-agriculture from 6.6 to 1.3 percent, construction 24.3 to -5.5 percent, and public administration and defense from 7.1 to 1.2 percent. The Karachi Stock Exchange did fall rapidly during the crisis, undoubtedly affected by contagion effects, but the fall began in 2006/07, both in terms of aggregate market capitalization and primary capital mobilization. The fall was more closely linked to sharp falls in corporate sector profitability after 2006. As discussed in Section 2, the global financial crisis after 2008 was associated with negative growth in the most trade-exposed sector of Pakistan's economy (manufacturing), and also declining exports, foreign portfolio investment, bank sector credit, and domestic investment, but by then the slowdown was already well established in Pakistan. Finally, Pakistan showed far more resilience to the global financial crisis than did many other developed and developing countries by maintaining positive GDP growth throughout. In 2008/09, GDP growth was negative in the world as a whole, in the Euro area, Japan, Malaysia, Singapore, Thailand, and South Korea; only a few countries, notably China and India, fared better than Pakistan (Government of Pakistan, 2011). Disappointment with Pakistan's growth should turn attention not to fatalism about the world economy but to domestic policy and governance reform. 


\section{References}

Ahmad, M. H., Alam, S., \& Butt, M. S. (2003). Foreign direct investment, exports and domestic output in Pakistan. Pakistan Development Review, 42(4), 715-723.

Ahmed, Q. M., Butt, M. S., \& Alam, S. (2000). Economic growth, export and external debt causality: The case of Asian countries. Pakistan Development Review, 39(4), 591-608.

Ahmed, V., \& Amjad, R. (1984). The management of Pakistan's economy, 1947-82. Karachi, Pakistan: Oxford University Press.

Aitken, B. J., \& Harrison, A. E. (1999). Do domestic firms benefit from FDI? Evidence from Venezuela. American Economic Review, 89(3), 605-618.

Akbar, M., \& Naqvi, N. F. (2000). Export diversification and the structural dynamics in the growth process: The case of Pakistan. Pakistan Development Review, 39(4), 573-589.

Akin, C., \& Kose, M. A. (2007). Changing nature of North-South linkages: Stylized facts and explanations (Working Paper No. 07/280). Washington, DC: International Monetary Fund.

Ali, T. (2008). The duel: Pakistan on the flight path of American power. London, UK: Simon and Schuster.

Amjad, R. (1982). Private industrial investment in Pakistan, 1960-1970. Cambridge, UK: Cambridge University Press.

Amjad, R. (1983). Industrial concentration and economic power. In H. Gardezi \& J. Rashid (Eds.), Pakistan: The roots of dictatorship: The political economy of a praetorian state. London, UK: Zed Press.

Andrews, D. (1993). Tests for parameter instability and structural change with unknown change point. Econometrica, 61, 821-856.

Aslam, N. (1987). The impact of foreign capital inflow on savings and investment: The case of Pakistan. Pakistan Development Review, 26(4), 787-789. 
Atique, Z., Khan, M. H., \& Azhar, U. (2004). The impact of FDI on economic growth under foreign trade regimes: A case study of Pakistan. Pakistan Development Review, 43(4), 707-718.

Balakrishnan, P., \& Parameswaran, M. (2007, July 14). Understanding economic growth in India: A prerequisite. Economic and Political Weekly, pp. 2915-2922.

Balasubramanyam, V. N., Salisu, M., \& Sapsford, D. (1996). Foreign direct investment and growth in EP and IS countries. Economic Journal, 106, 92-105.

Barro, R. J. (1991). Economic growth in a cross section of countries. Quarterly Journal of Economics, 106, 407-431.

Berthelemy, J.-C., \& Soderling, L. (2001). The role of capital accumulation, adjustment and structural change for economic growth take-off: Empirical evidence from African growth episodes. World Development, 29(2), 323-343.

Bhagwati, J. N. (2004). In defence of globalization. New York, NY: Oxford University Press.

Bhargava, S., \& Joshi, V. (1990, December 1). Increase in India's growth rate: Facts and a tentative explanation. Economic and Political Weekly, pp. 2657-2661.

Burki, S. J. (1999). Pakistan: Fifty years of nationhood. Boulder, CO: Westview Press.

Burki, S. J. (2007). Changing perceptions, altered reality: Pakistan's economy under Musharraf, 1999-2006. Karachi, Pakistan: Oxford University Press.

Burnside, C., \& Dollar, D. (2000). Aid, policies and growth. American Economic Review, 90(4), 847-868.

Cardoso, F. H. (1972). Dependency and development in Latin America. New Left Review, July-August, 83-95.

Chakraborty, C., \& Nunnenkamp, P. (2008). Economic reforms, FDI, and economic growth in India: A sector level analysis. World Development, 36(7), 1192-1212. 
Chaudhry, S. A. (1970). Private foreign investment in Pakistan. Pakistan Development Review, 10(1), 100-111.

Chow, G. (1960). Tests of equality between sets of coefficients in two linear regressions. Econometrica, 28(3), 591-605.

Dholakia, R. H. (1994, August 27). Spatial dimension of acceleration of economic growth in India. Economic and Political Weekly, pp. 23032309.

Din, M. U., Ghani, E., \& Siddique, O. (2003). Openness and economic growth in Pakistan. Pakistan Development Review, 42(4), 795-807.

Easterly, W., Kremer, M., Pritchett, L., \& Summers, L. (1993). Good policy or good luck: Country growth performance and temporary shocks. Journal of Monetary Economics, 32, 459-483.

Easterly, W., \& Levine, R. (2001). It's not factor accumulation: Stylized facts and growth models. World Bank Economic Review, 15(2), 177219.

Farid, A., \& Ashraf, J. (1995). Volatility at Karachi Stock Exchange. Pakistan Development Review, 34(4), 651-657.

Franco-Rodriguez, S., Morrissey, O., \& McGillivray, M. (1998). Aid and the public sector in Pakistan: Evidence with endogenous aid. World Development, 26(7), 1241-1250.

Frank, A. G. (1967). Capitalism and underdevelopment in Latin America. New York, NY: Monthly Review Press.

Gardezi, H., \& Rashid, J. (1983). Pakistan: The roots of dictatorship: The political economy of a praetorian state. London, UK: Zed Press.

George, A. L., \& Bennett, A. (2005). Case studies and theory development in the social sciences. Cambridge, MA: MIT Press.

Gerring, J. (2007). Case study research: Principles and practices. Cambridge, UK: Cambridge University Press.

Ghani, E., \& Din, M. U. (2006). The impact of public investment on economic growth in Pakistan. Pakistan Development Review, 45(1), 87-98. 
Gorg, H., \& Greenaway, D. (2004). Much ado about nothing? Do domestic firms really benefit from foreign direct investment? World Bank Research Observer, 19(2), 171-197.

Government of Pakistan. (2011). Pakistan Economic Survey, 2010-11. Islamabad: Author.

Griffin, K. B. (1965). Financing development plans in Pakistan. Pakistan Development Review, 5(4), 601-630.

Guillamont, P., \& Chauvet, L. (2001). Aid and performance: A reassessment. Journal of Development Studies, 37(6), 66-92.

Hameed, A., \& Ashraf, H. (2006). Stock market volatility and weak-form efficiency: Evidence from an emerging market. Pakistan Development Review, 45(5), 1029-1040.

Hansen, B. (1997). Approximate asymptotic p-values for structural change tests. Journal of Business and Economic Statistics, 15(1), 6067.

Hatekar, N., \& Dongre, A. (2005, April 2). Structural breaks in India's growth: Revisiting the debate with a longer perspective. Economic and Political Weekly, pp. 1432-1435.

Hausman, R., Pritchett, L., \& Rodrik, D. (2004). Growth accelerations (Mimeo). Harvard University, Cambridge, MA.

Husain, F., \& Mahmood, T. (2001). The stock market and the economy in Pakistan. Pakistan Development Review, 40(2), 107-114.

Husain, I. (1999). Pakistan: The economy of an elitist state. Karachi, Pakistan: Oxford University Press.

Husain, I. (2003). Economic management in Pakistan, 1999-2002. Karachi, Pakistan: Oxford University Press.

Iqbal, Z. (1993). Institutional variations in saving in Pakistan. Pakistan Development Review, 32(4), 1293-1311.

Iqbal, Z. (1994). Macroeconomic effects of adjustment lending in Pakistan. Pakistan Development Review, 33(4), 1011-1031. 
Iqbal, Z. (1997). Foreign aid and the public sector: A model of fiscal behavior in Pakistan. Pakistan Development Review, 36(2), 115-129.

Iqbal, Z., \& Zahid, G. M. (1998). Macroeconomic determinants of economic growth in Pakistan. Pakistan Development Review, 37(2), 125-148.

Islam, A. I. A. (1961). Pakistan's terms of trade. Pakistan Development Review, 1(2), 55-66.

Islam, N. (1972). Foreign assistance and economic development: The case of Pakistan. Economic Journal, 82(325), 502-530.

Joshi, V., \& Little, I. M. D. (1994). India: Macroeconomics and political economy, 1964-1991. New Delhi, India: Oxford University Press.

Kaur, P. (2007, April 14). Growth acceleration in India. Economic and Political Weekly, pp. 1380-1386.

Kemal, A. R., Din, M. U., \& Qadir, U. (2006). Economic growth in Pakistan. In K. S. Parikh (Ed.), Explaining growth in South Asia. New Delhi, India: Oxford University Press.

Kenny, C., \& Williams, D. (2001). What do we know about economic growth? Or why don't we know very much? World Development, 29(1), 1-22.

Khalid, A. M., \& Rajaguru, G. (2006). Financial market integration in Pakistan: Evidence using post-1999 data. Pakistan Development Review, 45(4), 1041-1053.

Khan, A. H., Hasan, L., \& Malik, A. (1992). Dependency ratio, foreign capital inflows and the rate of savings in Pakistan. Pakistan Development Review, 31(4), 843-856.

Khan, M. A., \& Qayyum, A. (2007). Trade liberalization, financial development and economic growth (Working Paper No. 19). Islamabad: Pakistan Institute of Development Economics.

Khan, M. A., Qayyum, A., \& Sheikh, S. A. (2005). Financial development and economic growth. Pakistan Development Review, 44(4), 819-837. 
Khan, M. H. (2000). The political economy of industrial policy in Pakistan, 1947-1971 (Working Paper No. 98). London, UK: School of Oriental and African Studies.

Khan, N. Z., \& Rahim, E. (1993). Foreign aid, domestic savings and economic growth (Pakistan: 1960 to 1998). Pakistan Development Review, 32(4), 1157-1167.

Khan, S. R. (1997). Has aid helped in Pakistan? Pakistan Development Review, 36(4), 947-957.

Khilji, N. M., \& Zampelli, E. (1991). The effect of US assistance on public and private expenditures in Pakistan: 1960-1988. Pakistan Development Review, 30(4), 1169-1184.

Kite, G., \& McCartney, M. (2011). A case for case studies: Economic growth in Pakistan, 1950/51 to 2008/09. Forthcoming.

Knowles, S., \& Garces-Ozanne, A. (2003). Government intervention and economic performance in East Asia. Economic Development and Cultural Change, 51(2), 451-477.

Krueger, A. O. (1998). Why trade liberalization is good for growth. Economic Journal, 108, 1513-1522.

Krugman, P. (1999). The return of depression economics. New York, NY: W. W. Norton.

Levine, R., \& Renelt, D. (1992). A sensitivity analysis of cross-country growth regressions. American Economic Review, 82(4), 942-963.

Lewis, S. R. (1969). Economic policy and industrial growth in Pakistan. London, UK: George Allen and Unwin.

Lewis, S. R. (1970). Pakistan: Industrialization and trade policies. London, UK: Oxford University Press.

Maddison, A. (1995). Monitoring the world economy, 1820-1992. Paris, France: Organisation for Economic Co-operation and Development.

Mahmood, Z., \& Qasim, M. A. (1992). Foreign trade regime and savings in Pakistan. Pakistan Development Review, 31(4), 883-893. 
McCartney, M. (2009). India: The political economy of growth, stagnation and the state, 1951-2007. London, UK: Routledge.

Mkandawire, T. (2001). Thinking about developmental states in Africa. Cambridge Journal of Economics, 25, 2989-3313.

Nachane, D. M. (2009, March 28). The fate of India unincorporated. Economic and Political Weekly, pp. 115-122.

Nagaraj, R. (1990, June 30). Growth rate of India's GDP, 1950/51 to 1987/88: Examination of alternative hypotheses. Economic and Political Weekly, pp. 1396-1403.

Nasir, S., \& Khalid, M. (2004). Saving investment behavior in Pakistan: An empirical investigation. Pakistan Development Review, 43(4), 665-682.

Nawab, S., Naqvi, H., \& Sarmad, K. (1984). Pakistan's economy through the Seventies. Islamabad: Pakistan Institute of Development Economics.

Nayyar, D. (2006, April 15). Economic growth in independent India: Lumbering elephant or running tiger? Economic and Political Weekly, pp. 1451-1458.

Papanek, G. F. (1967). Pakistan's development: Social goals and private incentives. Cambridge, MA: Harvard University Press.

Parikh, K. S. (Ed.). (2006). Explaining growth in South Asia. New Delhi, India: Oxford University Press.

Quandt, R. (1960). Tests of the hypothesis that a linear regression obeys two separate regimes. Journal of the American Statistical Association, $55,324-330$.

Qureshi, A. K., Din, M. U., Ghani, E., \& Abbas, K. (1997). Domestic resource mobilization for development in Pakistan. Pakistan Development Review, 36(4), 891-912.

Radhu, G. M. (1973). Transfer of technical know-how through multinational corporations in Pakistan. Pakistan Development Review, 12(4), 361-374. 
Rodrik, D. (2000, June). Can integration into the world economy substitute for a development strategy? Paper presented at the World Bank EBGDE European Conference.

Rodrik, D. (2003). Growth strategies (Mimeo). Harvard University, Cambridge, MA.

Rodrik, D., \& Subramanian, A. (2004). From 'Hindu growth' to productivity surge: The mystery of the Indian growth transition (Mimeo). Harvard University, Cambridge, MA.

Sachs, J. D., \& Warner, A. M. (1995). Economic reform and the process of global integration. Brookings Papers on Economic Activity, 1, 1-95.

Sarmad, K. (1992). External shocks and domestic adjustment in Pakistan 1970-1990. Pakistan Development Review, 31(4), 857-869.

Shabbir, T., \& Mahmood, A. (1992). The effects of foreign private investment on economic growth in Pakistan. Pakistan Development Review, 31(4), 831-841.

Shah, Z., \& Ahmed, Q. M. (2003). The determinants of foreign direct investment in Pakistan: An empirical investigation. Pakistan Development Review, 42(4), 697-714.

Sinha, A., \& Tejani, S. (2004, December 25). Trend break in India's GDP growth rate: Some comments. Economic and Political Weekly, pp. 5634-5639.

Stiglitz, J. E. (2002). Globalization and its discontents. London, UK: Penguin.

Stiroh, K. (2001). Information technology and the US productivity revival: What do the industry data say? New York, NY: Federal Reserve Bank of New York.

Tahir, R. (1995). Defence spending and economic growth: Re-examining the issue of causality for Pakistan and India. Pakistan Development Review, 34(4), 1109-1117.

Temple, J. (1999). The new growth evidence. Journal of Economic Literature, 37, 112-156. 
Uppal, J. Y. (1993). The internationalisation of the Pakistani stock market: An empirical investigation. Pakistan Development Review, 32(4), 605-618.

Van Rickenghem, C., \& Weder, B. (2001). Sources of contagion: Finance or trade? Journal of International Economics, 54, 293-308.

Vanaik, A. (1990). The painful transition: Bourgeois democracy in India. London, UK: Verso.

Virmani, A. (2005). India's economic growth history: Fluctuations, trends, break points and phases (Occasional Paper). New Delhi, India: Indian Council for Research on International Economic Relations.

Vogelsang, T. (1997). Wald-type tests for detecting shifts in the trend function of a dynamic time series. Economic Theory, 13, 818-849.

Wacziarg, R. (2002). Review of Easterly's 'The elusive quest for growth.' Journal of Economic Literature, 40, 907-918.

Wade, R. (1998). The Asian debt-and-development crisis of 1997-?: Causes and consequences. World Development, 26(8), 1535-1553.

Wallack, J. S. (2003, October 11). Structural breaks in Indian macroeconomic data. Economic and Political Weekly, pp. 4312-4315.

Wizarat, S. (2002). The rise and fall of industrial productivity in Pakistan. Karachi, Pakistan: Oxford University Press.

Wolf, M. (2004). Why globalization works: The case for the global market economy. London, UK: Yale University Press.

Zaidi, S. A. (2005). Issues in Pakistan's economy (2nd ed.). Karachi, Pakistan: Oxford University Press. 